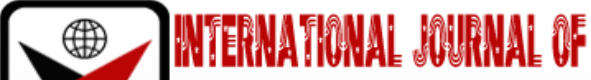

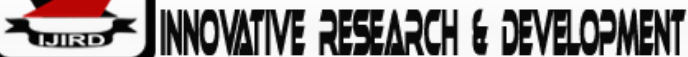

ISSN 2278 - 0211 (Online)

\section{Appropriate Instructional Method(S) for Teaching Entrepreneurship Education at Tertiary Level in Nigeria}

Tsua A. Godwin
Chief Lecturer, Department of Business Education,
Federal College of Education, Obudu, Cross River State, Nigeria
Gadzama Philemon S.
Lecturer, Department of Business Education, F.C.E. Obudu, Nigeria
Afebende Peter A
Lecturer, Department of Business Education, F.C.E Obudu, Nigeria
Effah Miriam A.
Lecturer, Department of Business Education, F.C.E Obudu, Nigeria
Angiating A. Godwin
Chief Librarian, Department of College Library, F.C.E Obudu, Nigeria
Adung David I.
College Librarian, Department of College Library, F.C.E. Obudu, Nigeria
Imbus Clement
Principal Librarian, Department of College Library, F.C.E Obudu, Nigeria
Ekpali David I.
Librarian, Department of College Library, F.C.E. Obudu, Nigeria

\section{Abstract:}

The study was designed to establish the best teaching method(s) that could be appropriate in imparting entrepreneurship skills to students at tertiary levels of education in Nigeria. The study adopted the descriptive survey design. The population for the study consisted of all students and teachers of General Studies courses-GST/GSS/GSEEntrepreneurship Studies/Education, in tertiary institutions spread across North-Central and South-South geopolitical zones in Nigeria. Simple random sampling technique was used to obtain a sample of twenty-five (25) teachers and two hundred and fifty (250) students of GST/GSS/GSE-Entrepreneurship Studies/ Education, from the five institutions selected for the study. Two separately structured questionnaires were used to elicit responses from the respondents- Teachers and Students. The instruments were structured based on the Likert's five -point rating scale. Data obtained was classified and translated into frequency tables. The mean and standard deviations were used to answer the research questions, while Pearson product moment correlation coefficient was used to determine the strength of relationship between the independent and the dependent variables and to test the hypotheses. The study revealed that Teachers of entrepreneurship education use lecture method and other traditional methods of teaching to give instructions on entrepreneurship education. The study also revealed that Teachers of entrepreneurship education do not employ extensive use of modern methods of teaching entrepreneurship education. Moreover, the study revealed that teachers of entrepreneurship education prefer the lecture method and discussion method of teaching in giving instructions in entrepreneurship education. The study recommends that: Teachers of entrepreneurship education should employ the lecture method in giving instructions in entrepreneurship courses. Teachers of entrepreneurship should also make use of the modern methods of teaching especially the business plan development method and the school industrial collaboration methods because of the potential benefits to enhance students understanding of entrepreneurship studies. Attempts should be made by teachers of entrepreneurship to make the courses interesting to students, especially students of non-business background or orientation. Teachers of entrepreneurship education should be subjected to retraining on modern methods of teaching entrepreneurship education to acquaint than with new skills and enable these teachers develop in the learners the positive skills of entrepreneurship.

Keywords: Instructional methods, teaching methods, entrepreneurship, entrepreneurship education, entrepreneurship skills

\section{Introduction}

Entrepreneurship education equips the learner with skills on decision making, acquisition of new ideas, methods of raising and maintaining conversations and establishing business relationships. It is the type of education which 
provides the learner the opportunity to make mistakes and learn from them to avoid future trial and errors. Though the Federal government of Nigeria recently introduced a policy to ensure all under graduate students of Nigeria's tertiary institutions undertake and pass at least one/two courses on entrepreneurship studies before graduation, appropriate methods of instruction have not been developed for this purpose. Teachers of entrepreneurship adopt any method of instruction of their choice. This is not proper because entrepreneurial skills are special and deserve specialized handling. Entrepreneurial skills which include imagination, ideation, innovativeness and creativity cannot be imparted anyhow, except through a carefully planned process of instruction. Such a carefully planned process of instruction is lacking as far as entrepreneurship education is concerned. The curriculum clearly shows that delivery of entrepreneurship education is not properly planned. Indeed, Katz (1991), argued that the key toa successful entrepreneurship education is to find the most effective way to manage the teachable skills and identify the best method between students' needs and teaching techniques. Therefore, it is expedient to take a closer look at the process of delivery of entrepreneurship education if it must succeed.

Entrepreneurship education per se is relatively new in the Nigerian educational system. It is very recently that this form of education started gaining prominence and recognition to be deliberately included in Nigeria's education curriculum. This means it is a type of education which requires specialized handling. Though the Federal Government of Nigeria, mandated all the Universities, Colleges of Education and Polytechnics in Nigeria to establish entrepreneurship courses as GST/GSS/GSE at B.Sc, N.C. E and N.D levels, the appropriate teaching/instructional methods and strategies have not been proffered. As a result, those saddled with the responsibility of teaching this noble subject grope in the dark. It is not enough to make a policy pronouncement! There should be adequate plans laid out for its implementation, which is lacking in entrepreneurship education. This has made the subject very uninteresting to the students/learners. Most of the learners assume (erroneously though) that entrepreneurship education is introduced into the education system to turn them into artisans and road side mechanics. Because, a standard programme of instruction for this type of education has not been designed to ensure its effective and efficient delivery to the learner/students. The lack of a standard and functional methods of instruction in entrepreneurship education also appears to be the reason for the low performance of Nigerian entrepreneurs. The prevalence and use of the most common teaching method-lecture method, seems to have failed to come up with desirable and plausible results. Hence, the need to search for the best or appropriate method of teaching entrepreneurship education at tertiary levels in Nigeria.

\subsection{Research Questions}

The following research questions were posed to guide the study:

- To what extent have teachers of entrepreneurship education employed the lecture method and other traditional teaching methods in giving entrepreneurship instructions at tertiary levels of education?

- To what have teachers of entrepreneurship education employed the use of modern methods of teaching rather the lecture method in giving instruction in entrepreneurship education?

- To what extent have teachers of entrepreneurship education used traditional and modern methods of teaching in entrepreneurship education?

- To what extent have teaching methods adopted enhanced students understanding of entrepreneurship education?

\subsection{Hypotheses}

The following hypotheses were formulated to guide the study:

- H0 I: There is no significant difference in the use of lecture method and other traditional methods of teaching entrepreneurship education.

- Ho II:There is no significant difference in the use of lecture method and the modern methods of teaching entrepreneurship education

- H0 III: There is no significant difference between the uses of traditional methods of teaching and the modern methods of teaching.

\section{Literature Review}

\subsection{Nature of Entrepreneurship Education}

Entrepreneurship education is the inculcation of skills to recognize, explore and exploit investment opportunities in order to establish and manage a business enterprise successfully (Garba, 2010, in Onwe\& Others, 2011). It is a carefully planned process that eventuates into the acquisition of entrepreneurial competencies.

Entrepreneurship education equips the learner with skills on decision making, acquisition of new ideas, methods of raising and maintaining conversations and establishing business relationships. It is the type of education which provides the learner the opportunity to make mistakes and learn from them to avoid future trial and errors.

Entrepreneurship education is the type of education aimed at preparing recipients on venturing into the establishment and management of an enterprise. It provides trainees with the knowledge, skills, competencies, attitudes, techniques and motivation that are required for entrepreneurial success in a variety of settings. In short, entrepreneurship education prepares the learners to become self-employed as well as an employer, rather than being employed for pay (Uduma\&Tsua, 2013).

Entrepreneurship education stretches across the cognitive, affective and psychomotor domains. This means that it encompasses intellectual creativity, character training and manipulative or motor skills. The three domains are harnessed in creating goods, services, searching, imagining, identifying, exploiting opportunities and bringing them to profitable 
ventures (Denga\&Denga, 2013). Entrepreneurship education inculcates entrepreneurial spirit, the spirit of independence and venturesomeness in its learners.

\subsection{Challenges of Entrepreneurship Education in Nigeria}

Entrepreneurship education is a recent development in Nigeria's educational history. Until recently little attempts were made by the Nigerian government to impart entrepreneurship skills. About a decade or so ago, the National Commission for Colleges of Education (NCCE) in its review of the NCE minimum standards considered it wise to include at least two compulsory courses on Entrepreneurship Education in the NCE Business Education curriculum.

The recent directive of the Federal Government of Nigeria, that all Higher Educational Institutions must include at least two (2) compulsory courses on entrepreneurship which should be taken by all students before they can be qualified to graduate with degrees, diplomas and certificates marked a turning point in the history of entrepreneurship education.

However, entrepreneurship education is bedeviled with a lot of challenges including;

- Entrepreneurship education is viewed with suspicion. As a new area of study emphasizing skill acquisition, most learners tend to suspect this form of education is intended to reduce them to 'road side mechanics' thereby depriving them from enjoying the good trappings of life hitherto enjoyed by their predecessors.

- Inadequacy of teaching/academic staff. Entrepreneurship education is a relatively new concept to the Nigeria's educational system, as a result, there is shortage of teaching/ academic staff. Denga and Denga (2013) argue that there is presently an acute shortage of teaching staff that are yet in the pipeline. Majority of academic staff handling the programmes are not specialists which threatens its success.

- The Problem of Funding: Entrepreneurship education programme is greatly challenged by funding.

- The challenge of a negative mindset. Old traditions die hard (Denga\&Denga 2013). Nigeriais used to an education system which creates the impression of utopia; as such graduates are only prepared to be engaged in jobs that do not involve physical and mental stress.

- $\quad$ Poor Infrastructure: Entrepreneurship must be supported by good roads, rail-lines, electricity, schools, hospitals and pipe-borne water which are functional. Nigeria lacks these and many others.

\subsection{Teaching/Instructional Methods}

According to Gage (1969, Ukoha and Eneogwe in Ogwo. 1996) teaching method is a recurrent pattern of teacher behavior, applicable to various subject matters, characteristics of more than one teacher and relevant to learning. Methods play vital role in ensuring effective, interesting and stimulating learning. In the same vein, teaching methods may also hinder learning (Ukoha and Eneogwe in Ogwo, 1996). This indicates that if a proper teaching method is not adopted in teaching a particular subject matter, learning could be discouraged. As a result, there are different teaching methods, including but not limited to the following.

\subsubsection{Project Method}

A project is a learning activity selected, planned, designed and executed by learners collectively or individually to clarify facts, acquire new knowledge, skills, appreciation, and to solve identified problems under the teacher's guidance and supervision. The underlying principle of the method is that concepts are comprehended through observation and that learning takes place through direct contact with materials.

\subsubsection{Discussion Method}

This involves communication of ideas, facts, and opinions by group of learners, on an identified and clearly stated instructional objective using skills as speaking, listening and non-verbal processes. For better student participation, a group size of 5 to 8 members, are considered manageable. Here, both the participants and the teacher pull their knowledge together to understand and appreciate a problem by learning from one another.

\subsubsection{Field Trip}

Field trip is an organized visit to a place of interest to achieve a stated instructional objective. It brings learners in close contact with realistic experiences which can hardly be achieved in the classroom no matter the honest intention of the teacher. By the contact, the learner(s) integrate knowledge and skills acquired through classroom instruction and laboratory practical with actual practice in the world of work.

\subsubsection{Problem Solving Method}

The basic requirements of this method are ability to reason and active thinking on the part of the learners. The responsibility of the teacher is to identify relevant problems in the various subject areas. Problem solving method has the potency of encouraging reflective thinking, creative expression of ideas, critical analysis of phenomenon and events, and logical reasoning in the learner.

\subsubsection{Demonstration Method}

Demonstration is the most effective in teaching skill or performance-oriented subject in the sciences, arts, vocational and technical education. Using the method, the teacher can explain steps in an operation, technique of handling a piece of apparatus, machine or hand tool, and procedures of handling or in carrying out an experiment while performing them. 


\subsubsection{Lecture Method}

Lecture involves a formal discourse or exposition on a subject matter to attain a stated instructional objective. The teacher does the talking while the learners listen and occasionally takes note. It is thus, the responsibility of the teacher to dish out or disseminate the knowledge to the learner who are supposedly ignorant and blank.

\subsection{Instructional Strategies in Entrepreneurship Education}

Instructional strategy in this context implies use or combination of instructional methods to achieve a better outcome in the teaching and learning process. Instructional strategy therefore does not identify specifically with any given method, but may embody two or more teaching techniques or methods or just a combination of some methods to achieve specific or general objectives of instruction. It is pertinent to point out that various instructional methods have been used in the area of entrepreneurship education.

Brethel (2007) argues that in the 21 $1^{\text {st }}$ century, the use of varied instructional strategies should be emphasized in all fields or disciplines. Their use should be consistent to ensure that lesson objectives are achieved, meaningfully to the advantage of both the teacher and students.

Daley (2007) posits those instructional strategies in entrepreneurship education should engage the students in experimental learning and lead them to observe interpret, analyze, make decisions and consider consequences. Instructional strategies in entrepreneurship education should conceptualize learning provide, students with opportunities to work and make reflection over an extended period of time, emphasize self-reliance and flexibility, provide diverse, ways of learning. By engaging students in entrepreneurship education class activities, teachers serve as facilitators allowing and enabling students to construct their own knowledge through learning application, action review and reflection.

Jones and George (2003) argue that in the past, the adoption of guided learning to the use of strength, weakness opportunities and threats in designing new business plan or carrying out feasibility studies have yielded good results in training young entrepreneurs.

\subsection{New Instructional Strategies in Entrepreneurship Education}

Oduma (2012) recommended the following in his study on strategies for improving the teaching of entrepreneurship education in tertiary institutions:

\subsubsection{TheBusiness Plan Development Instructional Strategy}

It involves the use of various approaches or combinations of teaching methods to enable the students understand how to develop and design a business plan or proposal. It is believed that the strategy will assist to focus the students to learn how to develop their own business ensure that students are given the opportunity to interact with successful entrepreneurs within their environment at programmed intervals.

\subsubsection{The School/Industrial Collaboration Instructional Strategy}

This is a programme of instruction that combines classroom teaching with students' temporary employment in industries or successful entrepreneurs. This strategy will afford the students the opportunity to establish mutual business links, entrepreneurship network and understanding with industrialist or experts. Functional entrepreneurship education requires that students are assist through instruction to establish a wide range of entrepreneurial network. They should understand the relevance of business monitoring and entrepreneurship monitoring.

\subsubsection{Laboratory Centered Instructional Strategy}

The strategy demands that practical oriented classes or tutorials should be taught with adequate and needed equipment in the laboratory. This helps the students especially those in vocational business education or Vocational technical education to develop saleable job skills which is a pre-requisite for entrepreneurship. The strategy must certainly involve the acquisition of practical or functional skills that will enable the prospective entrepreneur to establish and practice.

\subsubsection{The Case Studies/Analysis Approach}

This strategy affords the students the opportunity for field investigation. The strategy is expected to engage the students in practical feasibility studies and in critical review of business, plan, designs, proposal, problems and success as the case may be. Thus, studies about business success, weaknesses, opportunities and threats are all essential here to widen the students' horizon and spectrum of knowledge in various dimension of business and in fact entrepreneurship activities and experiences.

\subsubsection{The Computer Aided Instructional Strategy (CAisS)}

This involves the use of electronic medium and recorded tapes and disks, to enable the students understand more about entrepreneurship ideas, concepts and processes involved in practical operations and task. It is believed that the strategy will stimulate work place practices, as well as students' abilities to access information from the net and migrate or surf the web. 


\subsection{Theoretical Framework}

\subsubsection{Theory of Entrepreneurship}

\subsubsection{Joseph Schumpeter (1934)}

Schumpeter (1934) theorized that when the economy is in distress, profit motivated entrepreneurs will innovate, create and invent new things, products and services to stimulate productivity and job creation, thereby increasing wealth and profit (Egwu, Ogobonnaya, Ogunji, Oselebe and Udu (2014)

\subsubsection{Locus of Control}

Locus of control is an important aspect of personality. The concept was first introduced by Julian Rotter in the 1950s. Rotter (1966, in Kwabena,2011) refers to Locus of Control as an individual's perception about the underlying main causes of events in his/her life. In other words, a locus of control orientation is a belief about whether the outcomes of our actions are contingent on what we do (internal control orientation) or on events outside our personal control (external control orientation

In this context the entrepreneur's success comes from his/her own abilities and also support from outside.The former is referred to as internal locus of control and the latter is referred to as external locus of control. While individuals with an internal locus of control believe that they are able to control life events, individuals with an external locus of control believe that life's events are the result of external factors, such as chance, luck or fate. Empirical findings that internal locus of control is an entrepreneurial characteristic have been reported in the literature (Cromie, 2000, Ho and Koh, 1992; Koh, 1996; Robinson et al., 1991, Kwabena, 2011).

\subsubsection{Learning Theory}

\subsubsection{Gestalt Theory}

The Gestalt theory was to a great extent propagated by Köhler, Koffka and Wertheimer. This theory emphasized higher-order cognitive processes in the midst of behaviourism. Gestalt psychologists argued that we do not experience the world in simple, small chunks of information that enter our minds and are later combined into 6 complex ideas. Gestalt theory claimed that we experience the world in meaningful patterns or as an organised whole. Thus, knowledge is organised to solve a problem and therefore we should view learning from the perspective of problem solving. Gestalt theory postulates that knowledge is grouped into elements according to the following principles: proximity, similarity/differentiation, closure and simplicity (Gagne,1985).

\section{Methodology}

The study adopted the descriptive survey design. This design is usually applied in behavioural research related areas where variables can hardly be controlled or manipulated upon (Emaikwu, 2011).

Again, Kerlinger (1979), and Gilbert (1994) posit that survey research is one which involves the assessment of public opinions, attitudes and behaviour using questionnaire and sampling method. The population for the study consisted of all teachers and students of the General Studies courses, i.e., GSS/GST/GSE entrepreneurship, taken in the following tertiary institutions.

- University of Calabar, Calabar.

- Benue State University, Makurdi.

- Federal College of Education, Obudu.

- College of Education, Katsina-Ala

- Federal Polytechnic Idah

Simple random sampling technique was used to obtain the samples for the study in this order:

- Teachers: 5 teachers of entrepreneurship were sampled from each institution to obtain a sample of 25 respondents.

- Students: 50 students of GSS/GST/GSE entrepreneurship studies were randomly sampled to obtain a sample of 250 respondents.

The study area cut across tertiary institutions in two geopolitical zones; South-South and North-Central zones of Nigeria. Tertiary institutions in states in South- South include Cross River, Akwa-Ibom, Rivers, Bayelsa, Delta and Edo; while states in North- Central include Benue, Nassarawa, Kogi, Taraba, Niger and Kwara states. The two geopolitical zones represent important landmarks in the country. While South- South is the main stay of Nigeria's economy as producers of crude oil, North- Central zone is noted as the mainstay of Nigeria's 'stomach' economics. Two separately structured questionnaires were used to elicit responses; Teachers' Questionnaire and Students Questionnaire. Each of the instruments were structured based on the five-point Likert rating scale of Strongly Agree (SA), Agree (A), Undecided (U), Disagree (D) and Strongly Disagree (SD). Each of them will be attached nominal values of 5,4,3,2 and 1 respectively.

The two questionnaires (teachers' and students) were subjected to construct validity test. This enabled the researchers assess the extent to which the two instruments could measure what they purported to measure. Correlation analysis was used to achieve this after administering the instruments to a sample of the respondents in two institutions: University of Calabar and Federal College of Education, Obudu. The two instruments were variously subjected to reliability tests. A pilot test was carried out. The instruments were administered on ten (10) lecturers of entrepreneurship education 
courses and one hundred (100) students of University of Calabar and Federal College of Education, Obudu (i.e., five lecturers and fifty students respectively).

The instruments were subjected to Cronbach Alpha reliability test to measure the internal consistency of the instruments and the results were as follows

- Teachers' questionnaire had Cronbach Alpha $=0.881$

- $\quad$ Students' questionnaire had Cronbach Alpha = 0.876

Which show that the instruments were reliable. The questionnaires will be administered personally by research assistants to the target respondents. They were retrieved through the same process.

The data gathered from the responses to the structured questionnaires were classified and translated into frequency tables to enable calculation of Mean and Standard Deviation. Items with Mean scores of 3.5 and above were accepted while items with scores of less than 3.5 were rejected. A test of significance was applied to determine the acceptance or rejection region of stated hypotheses, using Pearson Product Moment Correlation Coefficient (r), to determine the strength of relationship between the independent variable and the dependent variables whose value is between $-1<\mathrm{r}<+1$ and is given as $\mathrm{r}=\frac{n \sum x y-\sum x, \sum y}{\sqrt{n \sum x^{2}-(x)^{2}} \sqrt{n \sum y^{2}-(y)^{2}}}$

Where $\mathrm{r}=$ correlation coefficient; $\mathrm{y}$ and $\mathrm{x}=$ variables of interest; $\mathrm{n}=$ number of respondents.

\section{Results}

Results of the study are presented below

\subsection{Research Question One}

To what extent have teachers of entrepreneurship education employed the lecture method and other traditional methods in giving entrepreneurship instructions at tertiary level of education?

Table 1: Lecture method and other traditional methods of teaching entrepreneurship education.

\subsubsection{Teachers 'Questionnaire}

\begin{tabular}{|c|c|c|c|c|c|c|c|c|c|c|}
\hline 1 & $\begin{array}{l}\text { I use these methods to teach } \\
\text { entrepreneurship studies }\end{array}$ & SA & $\mathbf{A}$ & $\mathbf{U}$ & D & SD & Total & Mean & SD & Remarks \\
\hline A & Project method & $\begin{array}{c}5 \\
25\end{array}$ & $\begin{array}{l}13 \\
52\end{array}$ & $\begin{array}{l}1 \\
3\end{array}$ & $\begin{array}{l}1 \\
2\end{array}$ & $\begin{array}{l}0 \\
0\end{array}$ & $\begin{array}{l}20 \\
95\end{array}$ & 4.75 & 0.7 & Accept \\
\hline B & Discussion method & $\begin{array}{c}7 \\
35 \\
\end{array}$ & $\begin{array}{l}11 \\
44 \\
\end{array}$ & $\begin{array}{l}1 \\
3\end{array}$ & $\begin{array}{l}1 \\
2\end{array}$ & $\begin{array}{l}0 \\
0\end{array}$ & $\begin{array}{l}20 \\
84\end{array}$ & 4.2 & 0.89 & Accept \\
\hline $\mathrm{C}$ & Field trip & $\begin{array}{c}2 \\
10\end{array}$ & $\begin{array}{l}12 \\
48\end{array}$ & $\begin{array}{c}5 \\
15\end{array}$ & $\begin{array}{l}1 \\
2\end{array}$ & $\begin{array}{l}0 \\
0\end{array}$ & $\begin{array}{l}20 \\
75\end{array}$ & 3.75 & 1.78 & Accept \\
\hline $\mathrm{D}$ & Lecture method & $\begin{array}{l}12 \\
60\end{array}$ & $\begin{array}{c}5 \\
20 \\
\end{array}$ & $\begin{array}{l}1 \\
3\end{array}$ & $\begin{array}{l}1 \\
2\end{array}$ & $\begin{array}{l}1 \\
1\end{array}$ & $\begin{array}{l}20 \\
86\end{array}$ & 4.3 & 1.1 & Accept \\
\hline $\mathrm{E}$ & Demonstration method0 & $\begin{array}{l}13 \\
65 \\
\end{array}$ & $\begin{array}{c}4 \\
16 \\
\end{array}$ & $\begin{array}{l}1 \\
3\end{array}$ & $\begin{array}{l}1 \\
2\end{array}$ & $\begin{array}{l}1 \\
1\end{array}$ & $\begin{array}{l}20 \\
87\end{array}$ & 4.35 & 0.1 & Accept \\
\hline $\mathrm{F}$ & Problem solving method & $\begin{array}{c}7 \\
35\end{array}$ & $\begin{array}{c}4 \\
16\end{array}$ & $\begin{array}{c}4 \\
12\end{array}$ & $\begin{array}{l}1 \\
2\end{array}$ & $\begin{array}{l}4 \\
4\end{array}$ & $\begin{array}{l}20 \\
96\end{array}$ & 3.45 & 1.5 & Reject \\
\hline
\end{tabular}

All the items have a mean score of more than 3.5 indicating that teachers of entrepreneurship employ the use of lecture method and traditional methods in giving entrepreneurship instructions, except problem-solving method which had a mean score of 3.45

\subsubsection{Students' Questionnaire}

\begin{tabular}{|c|c|c|c|c|c|c|c|c|c|c|}
\hline 1 & $\begin{array}{c}\text { Our entrepreneurship lecturer } \\
\text { Uses these methods to teach }\end{array}$ & & & & & & & & & \\
\hline A & Project method & 80 & 74 & 24 & 13 & 9 & 200 & 4.02 & 1.01 & Accept \\
& & 400 & 296 & 72 & 26 & 9 & 878 & & \\
\hline B & Discussion method & 115 & 58 & 19 & 2 & 6 & 200 & 4.35 & 0.92 & Accept \\
& & 575 & 232 & 52 & 4 & 6 & 583 & & & \\
\hline C & Field Trip & 37 & 38 & 45 & 31 & 49 & 200 & 2.92 & 1.41 & Reject \\
& & 185 & 152 & 165 & 62 & 49 & 665 & & & \\
\hline D & Demonstration method & 80 & 33 & 8 & 30 & 49 & 200 & 3.33 & 1.67 & Reject \\
& & 400 & 132 & 24 & 60 & 49 & 789 & & & \\
\hline E & Lecture method & 111 & 46 & 6 & 5 & 32 & 200 & 3.95 & 1.46 & Accept \\
& & 555 & 184 & 18 & 10 & 32 & 617 & & & \\
\hline F & Problem solving method & 52 & 39 & 31 & 30 & 48 & 200 & 3.09 & 1.68 & Reject \\
& & 260 & 156 & 93 & 60 & 48 & 930 & & & \\
\hline
\end{tabular}

Table 2 
Items A, B, \& E have mean score of more than 3.5, indicating that project method, discussion method and lecture method are methods extensively used in teaching the students, while items C, D, \& F have a mean scores of less than 3.5 to show that field trips, demonstration methods and problem-solving methods are not frequently in teaching the Research Question Two: to what extent have teachers of entrepreneurship education employed the use of modern methods of teaching rather than lecture method in giving instructions in entrepreneurship education?

Table 2: Use of Modern methods rather than lecture methods in giving instruction in entrepreneurship education

\subsubsection{Teachers' Questionnaire}

\begin{tabular}{|c|c|c|c|c|c|c|c|c|c|c|}
\hline 1 & $\begin{array}{c}\text { I also use these methods to teach } \\
\text { entrepreneurship studies }\end{array}$ & & & & & & & & & \\
\hline $\mathrm{A}$ & Business plan development method & $\begin{array}{c}2 \\
10\end{array}$ & $\begin{array}{l}13 \\
52\end{array}$ & $\begin{array}{l}1 \\
3\end{array}$ & $\begin{array}{l}0 \\
0\end{array}$ & $\begin{array}{l}4 \\
4\end{array}$ & $\begin{array}{l}20 \\
69\end{array}$ & 3.45 & 1.28 & Reject \\
\hline $\mathrm{B}$ & $\begin{array}{l}\text { School /industrial collaboration } \\
\text { method }\end{array}$ & $\begin{array}{c}2 \\
10\end{array}$ & $\begin{array}{c}7 \\
28\end{array}$ & $\begin{array}{c}7 \\
21\end{array}$ & $\begin{array}{l}0 \\
0\end{array}$ & $\begin{array}{l}4 \\
4\end{array}$ & $\begin{array}{l}20 \\
63\end{array}$ & 3.15 & 1.23 & Reject \\
\hline $\mathrm{C}$ & Laboratory centered method & $\begin{array}{c}2 \\
10 \\
\end{array}$ & $\begin{array}{l}2 \\
8\end{array}$ & $\begin{array}{l}10 \\
30 \\
\end{array}$ & $\begin{array}{l}1 \\
2\end{array}$ & $\begin{array}{l}5 \\
5 \\
\end{array}$ & $\begin{array}{l}20 \\
55\end{array}$ & 2.75 & 1.22 & Reject \\
\hline $\mathrm{D}$ & Case studies/analysis method & $\begin{array}{c}5 \\
25\end{array}$ & $\begin{array}{c}6 \\
24\end{array}$ & $\begin{array}{c}4 \\
12\end{array}$ & $\begin{array}{l}0 \\
0\end{array}$ & $\begin{array}{l}5 \\
5\end{array}$ & $\begin{array}{l}20 \\
66\end{array}$ & 3.30 & 1.49 & Reject \\
\hline $\mathrm{E}$ & $\begin{array}{l}\text { Computer guided instructional } \\
\text { method }\end{array}$ & $\begin{array}{c}3 \\
15\end{array}$ & $\begin{array}{c}8 \\
32\end{array}$ & $\begin{array}{c}4 \\
12 \\
\end{array}$ & $\begin{array}{l}0 \\
0\end{array}$ & $\begin{array}{l}5 \\
5\end{array}$ & $\begin{array}{l}20 \\
64\end{array}$ & 3.20 & 1.4 & Reject \\
\hline 6 & $\begin{array}{l}\text { I use lecturer, method in teaching } \\
\text { entrepreneurship course. }\end{array}$ & $\begin{array}{l}12 \\
60\end{array}$ & $\begin{array}{c}5 \\
20 \\
\end{array}$ & $\begin{array}{l}1 \\
3\end{array}$ & $\begin{array}{l}1 \\
2 \\
\end{array}$ & $\begin{array}{l}1 \\
1 \\
\end{array}$ & $\begin{array}{l}20 \\
86\end{array}$ & 4.3 & 1.1 & Accept \\
\hline 7 & $\begin{array}{c}\text { Lecture method is the best method } \\
\text { of teaching entrepreneurship } \\
\text { studies }\end{array}$ & $\begin{array}{c}9 \\
45\end{array}$ & $\begin{array}{c}5 \\
20\end{array}$ & $\begin{array}{l}0 \\
0\end{array}$ & $\begin{array}{l}1 \\
2\end{array}$ & $\begin{array}{l}5 \\
5\end{array}$ & $\begin{array}{l}20 \\
72\end{array}$ & 3.6 & 1.62 & Accept \\
\hline 8 & $\begin{array}{l}\text { Lecture method enhances student } \\
\text { understanding of entrepreneurship } \\
\text { studies }\end{array}$ & $\begin{array}{c}7 \\
35\end{array}$ & $\begin{array}{l}10 \\
40\end{array}$ & $\begin{array}{l}1 \\
3\end{array}$ & $\begin{array}{l}0 \\
0\end{array}$ & $\begin{array}{l}2 \\
2\end{array}$ & $\begin{array}{l}20 \\
80\end{array}$ & 4.0 & 1.14 & Accept \\
\hline
\end{tabular}

\section{Table 3}

Items 3A, B, C, D\& E have means scores of less than 3.5 indicating that modern methods of teaching are not used in giving instructions in entrepreneurship education. Whereas item $6,7, \& 8$ have mean scores of more than 3.5 , showing that the lecture method is preferred by the teachers in giving instruction in entrepreneurship education.

\subsubsection{Students Questionnaire}

\begin{tabular}{|c|c|c|c|c|c|c|c|c|c|c|}
\hline 1 & $\begin{array}{l}\text { Entrepreneur ships is taught to us } \\
\text { through Lecture method where } \\
\text { the students listen and take notes }\end{array}$ & $\begin{array}{l}126 \\
630\end{array}$ & $\begin{array}{c}49 \\
196\end{array}$ & $\begin{array}{c}9 \\
27\end{array}$ & $\begin{array}{c}9 \\
18\end{array}$ & $\begin{array}{l}7 \\
7\end{array}$ & $\begin{array}{l}200 \\
878\end{array}$ & 4.39 & 1.01 & Accept \\
\hline 2 & $\begin{array}{l}\text { I understand better when } \\
\text { entrepreneurship is taught using } \\
\text { lecture method }\end{array}$ & $\begin{array}{c}52 \\
260\end{array}$ & $\begin{array}{c}93 \\
372\end{array}$ & $\begin{array}{l}16 \\
48\end{array}$ & $\begin{array}{l}24 \\
48\end{array}$ & $\begin{array}{l}15 \\
15\end{array}$ & $\begin{array}{l}200 \\
743\end{array}$ & 3.72 & 1.19 & Accept \\
\hline 3 & $\begin{array}{l}\text { I understand better when our } \\
\text { teacher of entrepreneurship makes } \\
\text { the points and explains them }\end{array}$ & $\begin{array}{l}106 \\
530\end{array}$ & $\begin{array}{c}77 \\
308\end{array}$ & $\begin{array}{c}7 \\
21\end{array}$ & $\begin{array}{c}5 \\
10\end{array}$ & $\begin{array}{l}5 \\
5\end{array}$ & $\begin{array}{l}200 \\
870\end{array}$ & 4.35 & 0.87 & Accept \\
\hline 4 & $\begin{array}{l}\text { Our entrepreneurship lecturer also } \\
\text { Teaches using these method }\end{array}$ & & & & & & & & & \\
\hline $\mathrm{A}$ & Business plan development method & $\begin{array}{c}55 \\
279\end{array}$ & $\begin{array}{c}83 \\
332\end{array}$ & $\begin{array}{l}17 \\
51\end{array}$ & $\begin{array}{l}17 \\
34\end{array}$ & $\begin{array}{l}28 \\
28\end{array}$ & $\begin{array}{l}200 \\
720\end{array}$ & 3.60 & 1.34 & Accept \\
\hline B & $\begin{array}{l}\text { School/industrial collaboration } \\
\text { method }\end{array}$ & $\begin{array}{l}19 \\
95\end{array}$ & $\begin{array}{c}55 \\
220\end{array}$ & $\begin{array}{l}33 \\
99\end{array}$ & $\begin{array}{l}31 \\
62\end{array}$ & $\begin{array}{l}62 \\
62\end{array}$ & $\begin{array}{l}200 \\
538\end{array}$ & 2.69 & 1.40 & Reject \\
\hline $\mathrm{C}$ & Laboratory centered method & $\begin{array}{c}25 \\
125\end{array}$ & $\begin{array}{c}43 \\
172\end{array}$ & $\begin{array}{l}30 \\
90\end{array}$ & $\begin{array}{l}28 \\
56\end{array}$ & $\begin{array}{l}74 \\
74\end{array}$ & $\begin{array}{l}200 \\
517\end{array}$ & 2.59 & 1.47 & Reject \\
\hline $\mathrm{D}$ & Case studies /analysis method & $\begin{array}{c}32 \\
160\end{array}$ & $\begin{array}{c}62 \\
248\end{array}$ & $\begin{array}{l}19 \\
57\end{array}$ & $\begin{array}{l}21 \\
42\end{array}$ & $\begin{array}{l}66 \\
66\end{array}$ & $\begin{array}{l}200 \\
573\end{array}$ & 2.87 & 1.54 & Reject \\
\hline E & $\begin{array}{l}\text { Computer aided instructional } \\
\text { method }\end{array}$ & $\begin{array}{c}35 \\
175\end{array}$ & $\begin{array}{c}33 \\
132\end{array}$ & $\begin{array}{c}40 \\
120\end{array}$ & $\begin{array}{c}53 \\
106\end{array}$ & $\begin{array}{l}39 \\
39\end{array}$ & $\begin{array}{l}200 \\
572\end{array}$ & 2.86 & $1 . .37$ & Reject \\
\hline
\end{tabular}

Table 4

Items 3, 7, \& 8 have mean scores of more than 3.5, indicating that lecture method is the method teachers have been using to give instructions to students of entrepreneurship education. Whereas item $11 \mathrm{~B}, \mathrm{C}, \mathrm{D}$, \& E have mean scores of less than 3.5, while 11A has mean score of above 3.5 of the modern methods of teaching only business plan methods are used in giving instructions to students of entrepreneurship education.

- Research Question Three: to what extent have teachers of entrepreneurship education used traditional and modern methods of teaching in entrepreneurship education? 


\subsubsection{Teachers Questionnaire}

\begin{tabular}{|c|c|c|c|c|c|c|c|c|c|c|}
\hline 1 & $\begin{array}{l}\text { Which method of teaching } \\
\text { entrepreneurship studies do } \\
\text { you perfect? }\end{array}$ & & & & & & & & & \\
\hline & Project method & 1 & 13 & 0 & 2 & 4 & 20 & & & Reject \\
\hline I & & 5 & 52 & 0 & 4 & 4 & 65 & 3.25 & 1.3 & \\
\hline \multirow[t]{2}{*}{ Ii } & Discussion method & 10 & 4 & 2 & 2 & 2 & 20 & 3.9 & 1.37 & Accept \\
\hline & & 50 & 16 & 6 & 4 & 2 & 78 & & & \\
\hline \multirow[t]{2}{*}{ Iii } & Field trip & 5 & 8 & 2 & 4 & 1 & 20 & 3.6 & 1.2 & Accept \\
\hline & & 25 & 32 & 6 & 8 & 1 & 72 & & & \\
\hline \multirow[t]{2}{*}{ Iv } & Demonstration method & 10 & 4 & 2 & 2 & 2 & 20 & 3.9 & 1.37 & Accept \\
\hline & & 50 & 16 & 6 & 4 & 2 & 78 & & & \\
\hline \multirow[t]{2}{*}{$\mathrm{V}$} & Lecture method & 14 & 3 & 2 & 0 & 1 & 20 & 4.45 & 1.16 & Accept \\
\hline & & 70 & 12 & 6 & 0 & 1 & 89 & & & \\
\hline \multirow[t]{2}{*}{$\mathrm{Vi}$} & Problems solving method & 3 & 10 & 1 & 2 & 4 & 20 & 3.3 & 1.38 & Reject \\
\hline & & 15 & 40 & 3 & 4 & 4 & 66 & & & \\
\hline \multirow[t]{2}{*}{ Vii } & Business plan development & 4 & 9 & 2 & 1 & 4 & 20 & 3.4 & 2.12 & Reject \\
\hline & $\begin{array}{l}\text { method school / industrial } \\
\text { collaboration method }\end{array}$ & 20 & 36 & 6 & 2 & 4 & 48 & & & \\
\hline \multirow[t]{2}{*}{ Viii } & School/ Industrial collaboration & 5 & 2 & 11 & 1 & 1 & 20 & 3.45 & 1.07 & Reject \\
\hline & method & 25 & 8 & 33 & 2 & 1 & 69 & & & \\
\hline \multirow[t]{2}{*}{ Ix } & Laboratory centered method & 3 & 3 & 9 & 1 & 4 & 20 & 3.0 & 1.26 & Reject \\
\hline & & 15 & 12 & 27 & 2 & 4 & 60 & & & \\
\hline \multirow[t]{2}{*}{$\mathrm{X}$} & Case studies/ analysis method & 3 & 7 & 3 & 1 & 6 & 20 & 3.0 & 1.48 & Reject \\
\hline & & 15 & 28 & 9 & 2 & 6 & 60 & & & \\
\hline
\end{tabular}

Table 5: Use of Traditional and Modern Methods of Teaching In Entrepreneurship Education

From the table above, items 1ii, 1iii, $1 \mathrm{iv}$ and $1 \mathrm{v}$ have mean scores of more than 3.5. All the other items have mean scores of less than 3.5, indicating that the most preferred methods used in teaching entrepreneurship education are the traditional methods: lecture, discussion, demonstration and field trip methods.

\subsubsection{Students Questionnaire}

\begin{tabular}{|c|c|c|c|c|c|c|c|c|c|c|}
\hline $\mathbf{1}$ & $\begin{array}{c}\text { As a student of entrepreneurship, } \\
\text { which of the following method is best. }\end{array}$ & & & & & & & & \\
\hline A & Project method & 36 & 45 & 17 & 47 & 55 & 200 & 2.80 & 1.50 & Reject \\
& Discussion method & 180 & 180 & 51 & 94 & 55 & 560 & & \\
\hline B & Field Trip & 100 & 39 & 4 & 40 & 17 & 200 & 3.80 & 1.76 & Accept \\
& & 68 & 156 & 12 & 80 & 17 & 765 & & \\
\hline C & Demonstration method & 340 & 132 & 71 & 72 & 36 & 618 & & 1.51 & Reject \\
& & 82 & 24 & 18 & 34 & 42 & 200 & 3.35 & 1.68 & Reject \\
\hline D & Lecture method & 410 & 96 & 54 & 68 & 42 & 670 & & \\
\hline E & & 101 & 72 & 19 & 5 & 3 & 200 & 4.34 & 0.85 & Accept \\
& & 405 & 288 & 57 & 15 & 3 & 586 & & \\
\hline F & Problem solving method & 230 & 196 & 54 & 68 & 55 & 515 & & 1.63 & Reject \\
& & 51 & 53 & 14 & 30 & 52 & 200 & 2.86 & 1.58 & Reject \\
\hline G & Business plan development method & 255 & 162 & 42 & 60 & 52 & 571 & & \\
& & 30 & 38 & 80 & 17 & 35 & 200 & 3.06 & 1.30 & Reject \\
\hline H & School/industrial collaboration method & 150 & 152 & 240 & 34 & 35 & 611 & & \\
& & 18 & 44 & 42 & 53 & 43 & 200 & 2.71 & 1.20 & Reject \\
\hline I & Laboratory centered method & 90 & 176 & 126 & 106 & 43 & 541 & & \\
\hline J & Case studies /analysis method & 35 & 54 & 50 & 8 & 53 & 200 & 3.05 & 1.43 & Reject \\
& & 175 & 216 & 150 & 16 & 53 & 610 & & \\
\hline K & Computer aided instructional method & 40 & 27 & 41 & 44 & 48 & 200 & 3.32 & 1.52 & Reject \\
& & 200 & 204 & 123 & 88 & 48 & 663 & & \\
\hline
\end{tabular}

Table 6

All items have mean scores of less than 3.5, except items 1B \& E which have mean scores of more than 3.5 indicating that from the mirage of methods students prefer the lecture methods and discussion methods as a method of instruction in entrepreneurship education.

- $\quad$ Research Question Four: To what extent have teaching methods adopted enhanced students understanding of entrepreneurship education? 


\subsubsection{Teachers Questionnaire}

\begin{tabular}{|c|c|c|c|c|c|c|c|c|c|c|}
\hline 1 & $\begin{array}{c}\text { Students have always understood } \\
\text { the course(s) very well }\end{array}$ & $\begin{array}{c}9 \\
45 \\
\end{array}$ & $\begin{array}{c}8 \\
32 \\
\end{array}$ & $\begin{array}{l}2 \\
6 \\
\end{array}$ & $\begin{array}{l}1 \\
2 \\
\end{array}$ & $\begin{array}{l}\mathbf{0} \\
\mathbf{0}\end{array}$ & $\begin{array}{l}20 \\
85\end{array}$ & 4.25 & 0.83 & Accept \\
\hline 2 & Student pass course (s) very well & $\begin{array}{l}10 \\
50\end{array}$ & $\begin{array}{c}6 \\
24\end{array}$ & $\begin{array}{l}2 \\
6\end{array}$ & $\begin{array}{l}1 \\
2\end{array}$ & $\begin{array}{l}1 \\
1\end{array}$ & $\begin{array}{l}20 \\
83\end{array}$ & 4.15 & 1.21 & Accept \\
\hline 3 & $\begin{array}{l}\text { Teaching entrepreneurship using the } \\
\text { business plan method is better much }\end{array}$ & $\begin{array}{c}6 \\
30\end{array}$ & $\begin{array}{c}9 \\
36\end{array}$ & $\begin{array}{c}4 \\
12 \\
\end{array}$ & $\begin{array}{l}1 \\
2\end{array}$ & $\begin{array}{l}0 \\
0\end{array}$ & $\begin{array}{l}20 \\
80\end{array}$ & 4.0 & 0.84 & Accept \\
\hline 4 & $\begin{array}{l}\text { Entrepreneurship studies will be } \\
\text { better understood if the school / } \\
\text { industrial collaboration instruction } \\
\text { strategy is used }\end{array}$ & $\begin{array}{c}9 \\
45\end{array}$ & $\begin{array}{l}10 \\
40\end{array}$ & $\begin{array}{l}1 \\
3\end{array}$ & $\begin{array}{l}0 \\
0\end{array}$ & $\begin{array}{l}0 \\
0\end{array}$ & $\begin{array}{l}20 \\
88\end{array}$ & 4.2 & 0.68 & Accept \\
\hline 5 & $\begin{array}{l}\text { The laboratory centered instructional } \\
\text { strategy is very helpful in enhancing } \\
\text { the study of entrepreneurship }\end{array}$ & $\begin{array}{c}2 \\
10\end{array}$ & $\begin{array}{l}13 \\
52\end{array}$ & $\begin{array}{c}4 \\
12\end{array}$ & $\begin{array}{l}1 \\
2\end{array}$ & $\begin{array}{l}0 \\
0\end{array}$ & $\begin{array}{l}20 \\
76\end{array}$ & 3.8 & 0.68 & Accept \\
\hline 12 & $\begin{array}{l}\text { Teaching entrepreneurship study } \\
\text { through case studies /analysis, } \\
\text { approach enhance student } \\
\text { understanding. } \\
\end{array}$ & $\begin{array}{l}1 \\
5\end{array}$ & $\begin{array}{l}14 \\
56\end{array}$ & $\begin{array}{c}4 \\
12\end{array}$ & $\begin{array}{l}1 \\
2\end{array}$ & $\begin{array}{l}0 \\
0\end{array}$ & $\begin{array}{l}20 \\
75\end{array}$ & 3.75 & 0.72 & Accept \\
\hline 13 & $\begin{array}{l}\text { The use of computer aided } \\
\text { instructional strategy is useful in } \\
\text { teaching entrepreneurship studies. }\end{array}$ & $\begin{array}{c}5 \\
25\end{array}$ & $\begin{array}{l}12 \\
48\end{array}$ & $\begin{array}{l}2 \\
6\end{array}$ & $\begin{array}{l}1 \\
2\end{array}$ & $\begin{array}{l}0 \\
0\end{array}$ & $\begin{array}{l}20 \\
81\end{array}$ & 4.05 & 0.74 & Accept \\
\hline
\end{tabular}

Table 7: How Many Teaching Methods Adopted Enhanced Students Understanding of Entrepreneurship Education?

All the items have mean scores of more than 3.5, indicating that the methods of teaching used enhanced students understanding of entrepreneurship courses.

\subsubsection{Students Questionnaire}

\begin{tabular}{|c|c|c|c|c|c|c|c|c|c|c|}
\hline $\mathbf{1}$ & $\begin{array}{c}\text { I understand entrepreneurship } \\
\text { studies very well }\end{array}$ & $\mathbf{1 0 2}$ & $\mathbf{7 6}$ & $\mathbf{5}$ & $\mathbf{8}$ & $\mathbf{9}$ & $\mathbf{2 0 0}$ & $\mathbf{4 . 6 5}$ & $\mathbf{1 . 0 8}$ & Accept \\
\hline 2 & $\begin{array}{c}\mathbf{3 8 0} \\
\text { I can explain basic }\end{array}$ & 107 & 70 & 7 & $\mathbf{1 6}$ & $\mathbf{9}$ & $\mathbf{9 3 0}$ & & & \\
\hline 3 & $\begin{array}{c}\text { entrepreneurship concepts very } \\
\text { well }\end{array}$ & 535 & 280 & 21 & 16 & 8 & 860 & 4.30 & 0.79 & Accept \\
\hline $\begin{array}{c}\text { I have a good understanding of } \\
\text { entrepreneurship studies because } \\
\text { of the way our teacher handles the } \\
\text { course }\end{array}$ & 104 & 520 & 244 & 18 & 42 & 8 & 842 & 4.21 & 1.14 & Accept \\
\hline
\end{tabular}

Table 8

All items have a mean score of more than 3.5, indicating that students understand entrepreneurship studies and can even explain the concepts very well.

\subsection{Test of Hypotheses}

- $\quad$ Hypothesis One: There is no significant difference in the use of lecture method and other traditional methods of teaching entrepreneurship education.

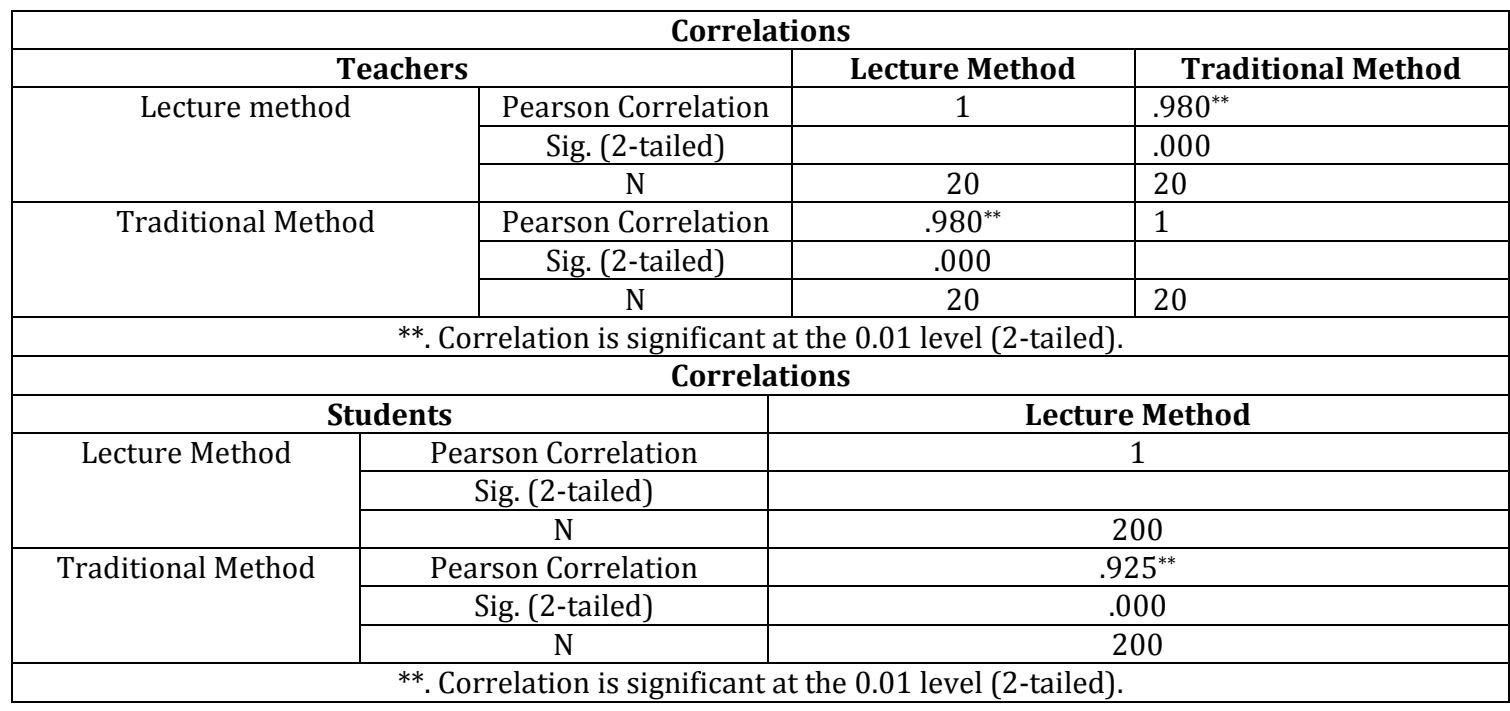

Table 9 


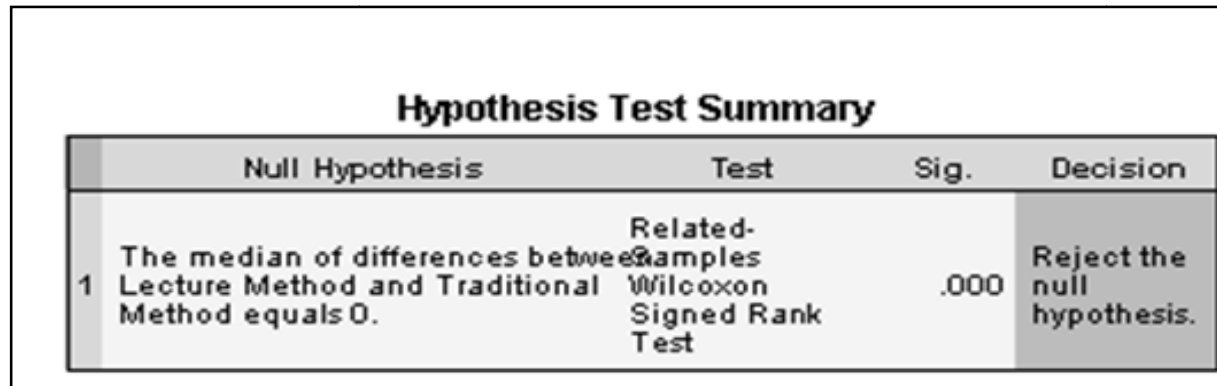

Asymptotic significances are displayed. The significance level is .05 .

Table 10: Correlations on Use of Lecture Method and Other Traditional Methods of Teaching Entrepreneurship Education

The results of $\mathrm{r}=0.980$ for (Teachers' responses) and $\mathrm{r}=0.925$ for (Student's responses) shows that correlation is significant at 0.01 level (2tailed-test). The null hypothesis is rejected and the alternative accepted.

- Hypothesis Two: There is no significant difference in the use of lecture method and the modern methods of teaching entrepreneurship education.

\begin{tabular}{|c|c|c|c|}
\hline \multicolumn{4}{|c|}{ Correlations } \\
\hline \multicolumn{2}{|c|}{ Teachers } & Lecture & Modern \\
\hline \multirow{3}{*}{$\begin{array}{l}\text { Lecture } \\
\text { Method }\end{array}$} & Pearson Correlation & 1 & $.928^{* *}$ \\
\hline & Sig. (2-tailed) & & .000 \\
\hline & $\mathrm{N}$ & 20 & 20 \\
\hline \multirow{3}{*}{$\begin{array}{l}\text { Modern } \\
\text { Method }\end{array}$} & Pearson Correlation & $.928^{* *}$ & 1 \\
\hline & Sig. (2-tailed) & .000 & \\
\hline & $\mathrm{N}$ & 20 & 20 \\
\hline \multicolumn{4}{|c|}{ **. Correlation is significant at the 0.01 level (2-tailed). } \\
\hline \multicolumn{4}{|c|}{ Correlations } \\
\hline \multirow{2}{*}{\multicolumn{2}{|c|}{ Students }} & Lecture & Modern \\
\hline & & Method & Method \\
\hline \multirow{3}{*}{$\begin{array}{l}\text { Lecture } \\
\text { Method }\end{array}$} & Pearson Correlation & 1 & $.881^{* *}$ \\
\hline & Sig. (2-tailed) & & .000 \\
\hline & $\mathrm{N}$ & 200 & 200 \\
\hline \multirow{3}{*}{$\begin{array}{l}\text { Modern } \\
\text { Method }\end{array}$} & Pearson Correlation & $.881^{* *}$ & 1 \\
\hline & Sig. (2-tailed) & .000 & \\
\hline & $\mathrm{N}$ & 200 & 200 \\
\hline
\end{tabular}

Table 11: Correlation on the Use of Lecture Method and Modern Methods of Teaching Entrepreneurship

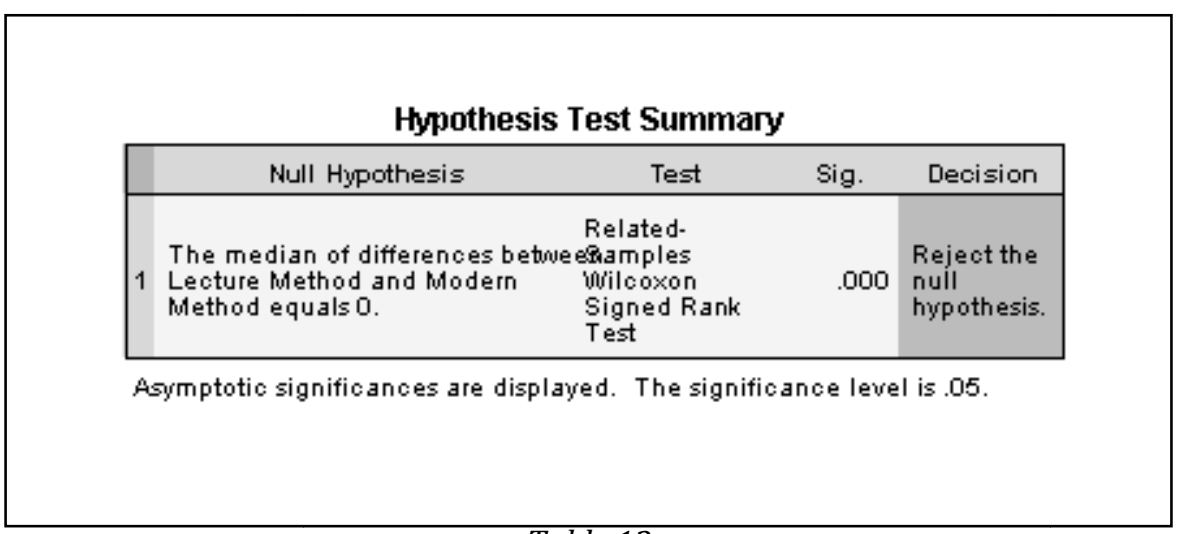

Table 12

The results of $r=0.928$ (Teachers' responses) and $r=0.881$ (Students' responses) show significant correlation at 0.05 level (2tailed-test), therefore the null hypothesis is rejected and the alternative hypothesis accepted.

- Hypothesis Three: There is no significant difference between the use of traditional methods of teaching and the modern methods of teaching. 


\begin{tabular}{|c|c|c|c|}
\hline \multicolumn{4}{|c|}{ Correlations } \\
\hline \multicolumn{2}{|c|}{ Teachers } & Traditional & Modern \\
\hline \multirow{3}{*}{$\begin{array}{l}\text { Traditional } \\
\text { method }\end{array}$} & Pearson Correlation & 1 & $.973^{* *}$ \\
\hline & Sig. (2-tailed) & & .000 \\
\hline & $\mathrm{N}$ & 20 & 20 \\
\hline \multirow[t]{3}{*}{ Modern Method } & Pearson Correlation & $.973^{* *}$ & 1 \\
\hline & Sig. (2-tailed) & .000 & \\
\hline & $\mathrm{N}$ & 20 & 20 \\
\hline \multicolumn{4}{|c|}{ **. Correlation is significant at the 0.01 level (2-tailed). } \\
\hline \multicolumn{4}{|c|}{ Correlations } \\
\hline \multicolumn{2}{|c|}{ Students } & $\begin{array}{l}\text { Traditional } \\
\text { Method }\end{array}$ & $\begin{array}{l}\text { Modern } \\
\text { Method }\end{array}$ \\
\hline \multirow{3}{*}{$\begin{array}{l}\text { Traditional } \\
\text { Method }\end{array}$} & Pearson Correlation & 1 & $.983^{* *}$ \\
\hline & Sig. (2-tailed) & & .000 \\
\hline & $\mathrm{N}$ & 200 & 200 \\
\hline \multirow[t]{3}{*}{ Modern Method } & Pearson Correlation & $.983^{* *}$ & 1 \\
\hline & Sig. (2-tailed) & .000 & \\
\hline & $\mathrm{N}$ & 200 & 200 \\
\hline
\end{tabular}

Table 13: Correlation on the Use of Traditional Methods and Modern Methods of Teaching Entrepreneurship Education

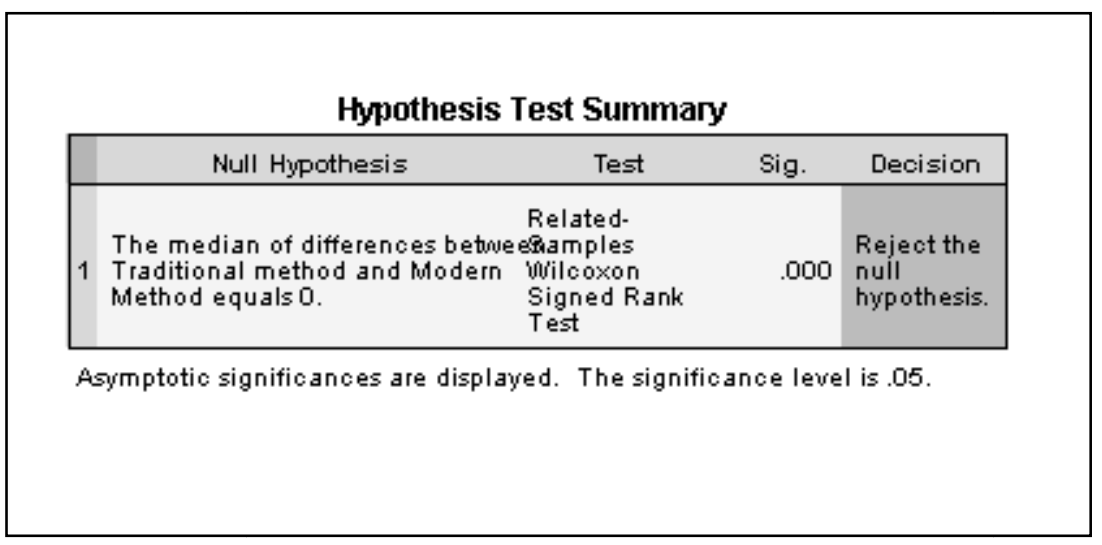

Table 14

The results of $r=0.973$ (Teachers' responses) and $r=0.983$ (Students' responses) show a significant correlation at 0.01 level ( 2 tailed- test), therefore the null hypothesis is rejected and the alternative hypothesis accepted.

\section{Discussion}

The study revealed that Teachers of entrepreneurship education, use lecture method and other traditional methods of teaching to give instructions on entrepreneurship education. This is in agreement with Solomon, et al, (2002) whose study highlighted that the most popular teaching methods in entrepreneurship education are creation of business plans, case studies and lectures. It is clear that the lecture method is extensively used in giving entrepreneurship education at tertiary levels. The study also revealed that Teachers of entrepreneurship education do not employ extensive use of modern methods of teaching entrepreneurship education. This finding agrees with the view of European Commission, Directorate-General for Enterprise and Industry (2009), that providing teachers with adequate competences to teach entrepreneurship is seen as a major challenge. There seems to be a deficit of specific skills among teachers. The current situation is that most teachers have not been trained in entrepreneurship. Consequently, they may be unaware of the right approach to entrepreneurship teaching. So, this finding further demonstrates that lecture method of teaching is extensively used by teachers of entrepreneurship education. Moreover, the study revealed that teachers of entrepreneurship education prefer the lecture method and discussion method of teaching in giving instructions in entrepreneurship education.

\section{Conclusion/Recommendations}

There are several methods of teaching applied to entrepreneurship education: Traditional methods of teaching include; lecture, demonstration, project, field trip, discussion and problem-solving methods. The modern methods include business plan, school/industrial collaboration, laboratory centred, case studies analysis and computer aided instructional methods that could be used in teaching entrepreneurship courses. This study has revealed that the most extensively used method of teaching entrepreneurship is the lecture method. Though other traditional methods are also employed in giving 
instructions, the most preferred method of teaching is the lecture method. The study also reveals that this method of teaching enhanced students understanding of entrepreneurship courses.

The study recommends as follows:

- Teachers of entrepreneurship education should employ the lecture method in giving instructions in entrepreneurship courses.

- Teachers of entrepreneurship should make use of the modern methods of teaching especially the business plan development method and the school industrial collaboration methods because of the potential benefits to enhance students understanding of entrepreneurship studies.

- Attempts should be made by teachers of entrepreneurship to make the courses interesting to students, especially students of non-business background or orientation.

- Teachers of entrepreneurship education should be subjected to retraining on modern methods of teaching entrepreneurship education to acquaint than with new skills and enable these teachers develop in the learners the positive skills of entrepreneurship.

\section{References}

i. Agburu, J.I (2001). Modern Research Methodology. Makurdi: The Solid Printing and Pub. Coy.

ii. Akpa, A, \&Angahar, P (1999). Essentials of Research Methology. Lagos: Aboki Publishers

iii. Anderson, B.O (2007), Teaching entrepreneurship education in high school. Strategies and approaches. http:www.entre.edu.appr/str/html.

iv. Anderson, B.O (2007). Teaching entrepreneurship education in high school. Strategies and approaches. http:www.entre.edu.appr/str/html.

v. Ashmore, A. S (2007). The third wave of entrepreneurship education. Strategies for teaching entrepreneurship.

vi. Bandura, C (1980) strategies of the social cognitive theory of learning. www.franceedu.learning,theory.com/vnedu.

vii. Birla, H. O (2012). Evolution and theories of Entrepreneurship. A critical Review on the Kenyan perspective. International Journal of Business and Commerce. 1(11) (Retrieved 20/8/16).

viii. Brethel, C. M (2007) Lecturer perception on the teaching strategies utilized in education and entrepreneurship student centred teaching strategies. Rmc.upom.edu.my/...lectures.

ix. Daley, M.N (2007). Instructional strategies for developing entrepreneurship education...teaching strategies retrieved $16^{\text {th }}$ June 2010 from www.edudigest.on/ 2007.

x. $\quad$ Denga, D.I. \&Denga, H.N. (2013) Entrepreneurship Education: Emerging Trends and the Human Engineering Paradigm. Calabar; Clearlines Pub.

xi. Development: An overview Association of Business Educators of Nigeria (ABEN) Book of readings 1 (11), 8.

xii. Egwu, E.U., Ogbu,O., Ogunji, J., Oselebe, H.\&Udu, A.A.(Eds) Entrepreneurship \&Intrapreneurship: Principle and Practice. Book of Readings. Abakiliki; Ebonyi State university press

xiii. Emaikwu, S. O. (2011). Fundamentals of Research Methods and Statistics. Makurdi: Seifers Press.

xiv. Emmanuel, C. L. (2006) Entrepreneurship: A Conceptual Approach. Lagos; Pumark Nigeria Ltd.

xv. European Commission, Directorate-General for Enterprise and Industry Unit (in Usioboh, S.A. and Akpomudjere, 0. (2011). Business education and entrepreneurship in Nigeria: teaching entrepreneurship in business education. ABEN Book of readings, $1 ; 11$

xvi. Gagne, R (1985). The conditions of learning. New York. Holt, Rinehart and Winston.

xvii. Katz, J.A. (1991). Endowed positions: entrepreneurship and related fields. Entrepreneurship theory and practice. 15(3):53-67

xviii. Kerlinger, F. N (1979). Foundation of Behavioural Research. New York: Holt, Richard \& Winston.

xix. Kwabena, N. S. (2011) Entrepreneurship theories and Empirical Research A summary review of literature European |journal of \business and |management 3(6) (Retrieved 20/8/16).

xx. Nelson, R.E \& Johnson, S. D (2008). Teaching of entrepreneurship development education. A strategic approach to economic growth in Kenya. Journal of industrial teacher education 35(1), pp.7$21<$ http://scholar.lib.vt.edu/ejournals/jite/v.35.nl

xxi. Njoku, R., Amara, T and Okpata, F. (nd). Introduction to Entrepreneurship

xxii. NUC/NBTE Entrepreneurship Education Series.

xxiii. Oduma, C. A (2012). Fundamental of entrepreneurial education: the issue of instructional strategy in entrepreneurship education. Citizen advocate press, p.69-75.

xxiv. Ogwo, B. (1996) (Ed). Curriculum Development and Educational TechnologyMakurdi: Onaivi Printing Press.

xxv. Onwe S.O; Dim, C.N and Ukeje, I.O. (2011). Entrepreneurship studies; An Introductory Approach. Enugu: Dimcov Publishers.

xxvi. Onyemah, L.N. (2011). Prospects of Entrepreneurship Development in National

xxvii. Skinner, B.F (1966). Science and \human Behaviour. New York Macmillan (Retrieved 20/8.16)

xxviii. Uduma, M.K. and Tsua A.G (2013). Basic Entrepreneurship Development. Tsar-Vandeikya: Divine Business Communication.

xxix. Gilbert, B.A. (1994). Empirical Foundations of Educational Research. New Jersey: Prentice Hall Inc. 